Article

\title{
Acylphloroglucinol Derivatives from the South African Helichrysum niveum and Their Biological Activities
}

\author{
Olugbenga K. Popoola ${ }^{1}$, Jeanine L. Marnewick ${ }^{2}$, Fanie Rautenbach ${ }^{2}$, Emmanuel I. Iwuoha ${ }^{1}$ \\ and Ahmed A. Hussein 1,*
}

1 Chemistry Department, University of Western Cape, Private Bag X17, Bellville 7535, South Africa; E-Mails: 3318925@myuwc.ac.za (O.K.P.); eiwuoha@uwc.ac.za (E.I.I.)

2 Oxidative Stress Research Centre, Faculty of Health and Wellness Sciences, Cape Peninsula University of Technology, P. O. BOX 1906, Bellville 7535, South Africa; E-Mails: MarnewickJ@cput.ac.za (J.L.M.); rautenbachf@cput.ac.za (F.R.)

* Author to whom correspondence should be addressed; E-Mail: ahmohammed@uwc.ac.za; Tel.: +27-21-959-2262; Fax: 27-21-959-3055.

Academic Editor: Jean-Marc Sabatier

Received: 23 July 2015 / Accepted: 10 September 2015 / Published: 18 September 2015

\begin{abstract}
Phytochemical investigation of aerial parts of Helichrysum niveum (H. niveum) using different chromatographic methods including semi-preparative HPLC afforded three new (1-3) and six known (4-10) acylphloroglucinols alongside a known dialcohol triterpene (11). The structures of the isolated compounds were characterized accordingly as 1-benzoyl-3 (3-methylbut-2-enylacetate)-phloroglucinol (helinivene A, 1), 1-benzoyl-3 (2S-hydroxyl-3methylbut-3-enyl)-phloroglucinol (helinivene B, 2), 8-(2-methylpropanone)-3S,5,7-trihydroxyl2,2-dimethoxychromane (helinivene C, 3), 1-(2-methylbutanone)-4-O-prenyl-phloroglucinol (4), 1-(2-methylpropanone)-4-O-prennyl-phloroglucinol (5), 1-(butanone)-3-prenyl-phloroglucinol (6), 1-(2-methylbutanone)-3-prenyl-phloroglucinol (7), 1-butanone-3-(3-methylbut-2-enylacetate)phloroglucinol (8), 1-(2-methylpropanone)-3-prenylphloroglucinol (9), caespitate (10), and 3 $\beta$-24-dihydroxyterexer-14-ene (11). Excellent total antioxidant capacities were demonstrated by helinivenes A and B (1 and $\mathbf{2}$ ) when measured as oxygen radicals absorbance capacity (ORAC), ferric-ion reducing antioxidant power (FRAP), trolox equivalent absorbance capacity (TEAC) and including the inhibition of $\mathrm{Fe}^{2+}$-induced lipid peroxidation $\left(\mathrm{IC}_{50}=5.12 \pm 0.90\right.$; $3.55 \pm 1.92) \mu \mathrm{g} / \mathrm{mL}$, while anti-tyrosinase activity at $\mathrm{IC}_{50}=35.63 \pm 4.67$ and $26.72 \pm$ $5.05 \mu \mathrm{g} / \mathrm{mL}$ were also observed for $\mathbf{1}$ and $\mathbf{2}$, respectively. This is the first chemical and in vitro biological study on $H$. niveum. These findings underpin new perspectives for the
\end{abstract}


exploitation of these natural phenolic compounds in applications such as in the natural cosmeceutical and pharmaceutical sectors.

Keywords: Helichrysum niveum; asteraceae; phloroglucinols; antioxidant; anti-aging

\section{Introduction}

The systemic process of aging in humans results in an imbalance between synthesis and degradation of the extracellular matrix. Overproduction of degradative enzymes and oxygen free radicals during chronological and photo-induced aging leads to degradation of the network and elastic skin collagen and hyper-synthesis of melanin. It is a complex process with multiple underlying influences including the probable involvement of inheritable and various environmental factors [1] that represents a major burden to the health care system. Aging is attributed to, but not limited to, the excessive accumulation of free radicals and other forms of reactive oxygen species (ROS), which are primarily generated in the body as a result of physiological and biochemical processes [2]. Other notable ways of accumulating ROS in the body, is through continuous body contact with a series of environmental cues (such as ultra-violet radiation and pollution), and lifestyle choices including (but not limited to) diet, smoking, status of concurrent diseases (e.g. diabetes), exercise and alcohol consumption [3]. Free radical accumulation, when above threshold level in the body, can cause cellular oxidative damage to important macromolecules such as proteins, lipids and deoxy nucleic acid (DNA), eventually leading to many chronic diseases such as cancer, aging and neurodegenerative disorders [4], and other degenerative diseases in humans [2]. The biologically relevant consequences of ultra-violet-A (UVA) exposure therefore include mainly photo-ageing and photocarcinogenesis [5].

Helichrysum niveum (L.) Less. (H. niveum) (synonyms; Gnaphalium niveum L., Helichrysum ericifolium Less. var. metalasioides (DC.) Harv., Helichrysum metalasioides (DC.) is an indigenous plant widely distributed along the Western Cape coast of South Africa, often on dunes and sandy soil. It has distinguishable acute white bracts, which is where its name niveum, or "snow white" plant [6] originated. From SciFinder and the dictionary of natural products database, no reports on scientific or ethno-medicinal value have been recorded. Our proposition was based on the chemotaxonomic relationship, which may possibly exist between H. niveum and other Helichrysum species. Previous findings expanded the knowledge about the phenolic profile of Helichrysum to be richly blessed with a large proportion of phloroglucinol derivatives [7-12] and terpenoids [13] among others. Dimeric phloroglucinols including arzanol with notable antioxidant, anti-inflammatory and antibacterial activities [13-15], has been documented in several Helichrysum species.

Following the ongoing exploration of untapped South African Helichrysum species embarked upon by our research group, we had previously documented scientific data on the biological application of South African Helichrysum teretifolium constituents as modulators of oxidative stress and skin aging [16]. The preliminary screening of the total extract of $H$. niveum showed very strong anti-oxidative capacity and an interesting chemical profile in the TLC analysis. Accordingly, we prioritized this plant extract and submitted it to phytochemical studies. The objective of this work was also directed to investigate the secondary metabolites of a methanol extract of $H$. niveum with a particular focus on the phenolic 
compounds and investigate them for possible total antioxidant capacity, as well as the tyrosinase, elastase and cholinesterase inhibitory activities.

\section{Results and Discussion}

The presence of terpenes and high amount of phenolics was first recognized by preliminary thin layer chromatographic screening of a methanol extract. Ten phloroglucinols derivatives (1-10) and a triterpene (11) were isolated from $H$. niveum. Their chemical structures were elucidated by extensive analyses of spectroscopic data (Tables 1 and 2) as well as correlations with published data on literature. Three of the isolated compounds, helinivenes A-C (1-3) were reported for the first time. The total antioxidant capacities measured as FRAP, TEAC, ORAC and the inhibition of Fe (II)-induced microsomal lipid peroxidation ability of the total extract and its constituents are presented in Table 3 , while the inhibition of aging-related enzymes measured using mushroom tyrosinase, elastase from pancreas porcine and acetylcholinesterase are presented in Table 4.
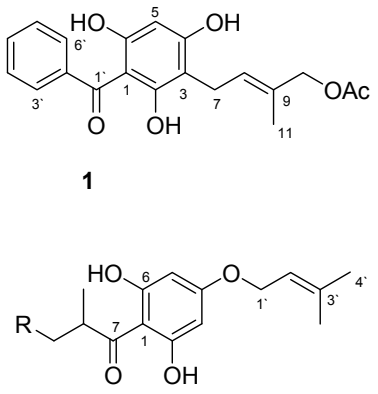

$$
\begin{aligned}
& 4 \mathrm{R}=\mathrm{Me} \\
& 5 \mathrm{R}=\mathrm{H}
\end{aligned}
$$

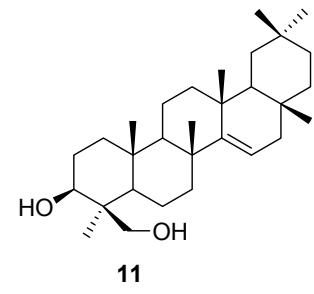

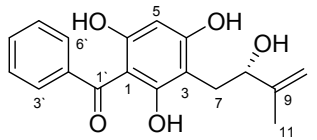

2

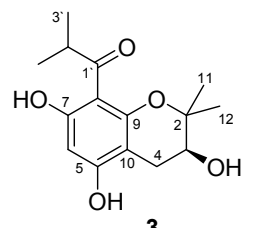

3

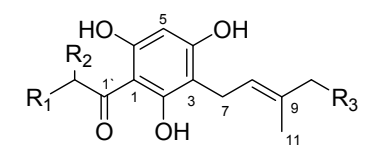

$6 \mathrm{R}_{1}=\mathrm{C}_{2} \mathrm{H}_{5} ; \mathrm{R}_{2}=\mathrm{H} ; \mathrm{R}_{3}=\mathrm{H}$

$7 \mathrm{R}_{1}=\mathrm{C}_{2} \mathrm{H}_{5} ; \mathrm{R}_{2}=\mathrm{CH}_{3} ; \mathrm{R}_{3}=\mathrm{H}$

$8 \quad \mathrm{R}_{1}=\mathrm{C}_{2} \mathrm{H}_{5} ; \mathrm{R}_{2}=\mathrm{H} ; \quad \mathrm{R}_{3}=\mathrm{OAC}$

$9 \mathrm{R}_{1}=\mathrm{CH}_{3} ; \mathrm{R}_{2}=\mathrm{CH}_{3} ; \mathrm{R}_{3}=\mathrm{H}$

$10 \mathrm{R}_{1}=\mathrm{CH}_{3} ; \mathrm{R}_{2}=\mathrm{CH}_{3} ; \mathrm{R}_{3}=\mathrm{OAC}$

Figure 1. Chemical structures of compounds 1-11 isolated from H. niveum.

Compound 1 was obtained as yellow amorphous powder with UV (MeOH) spectrum showed $\lambda_{\max }$ at $300 \mathrm{~nm}$. IR (KBr) spectrum showed absorption bands due to hydroxyl $\left(3300 \mathrm{~cm}^{-1}\right)$, carbonyl $\left(1800 \mathrm{~cm}^{-1}\right)$, terminal $\mathrm{C}=\mathrm{C}\left(1680 \mathrm{~cm}^{-1}\right)$, and aromatic $\left(1410 \mathrm{~cm}^{-1}\right)$. Its molecular formula was determined as $\mathrm{C}_{20} \mathrm{H}_{20} \mathrm{O}_{5}$. NMR data (Tables 1 and 2) showed signals corresponding to di-substituted phloroglucinol at $\delta_{\mathrm{H}} 6.07 \mathrm{~s} ; \delta_{\mathrm{C}} 104.5,163.4,106.4,163.2,160.0(\mathrm{C} /$ each $), 96.0(\mathrm{CH})$, benzoyl group at $\delta_{\mathrm{H}} 7.59-7.38(5 \mathrm{H}) ; \delta_{\mathrm{C}} 200.3(\mathrm{CO}), 143.0$ (C), 128.4 (X 2), 129.1 (X 2), 131.6, (CH/each) and a prenyl group with oxygenated and acetylated methyl terminal at $\delta_{\mathrm{H}} 1.71\left(\mathrm{CH}_{3} \delta_{\mathrm{C}} 21.6\right), 3.38\left(\mathrm{CH}_{2}, \mathrm{~d}, 7.5 \mathrm{~Hz}\right.$, $\left.\delta_{\mathrm{C}} 21.9\right), 4.82\left(\mathrm{CH}_{2}, \mathrm{~s}, \delta_{\mathrm{C}} 63.7\right), 5.54\left(\mathrm{CH}, \mathrm{t}, 7.5 \mathrm{~Hz}, \delta_{\mathrm{C}} 129.2(\mathrm{CH})\right.$ and $130.4(\mathrm{C})$. The ${ }^{1} \mathrm{H}-\mathrm{NMR}$ of 1 is very similar with 1-benzoyl-3-prenyl phloroglucinol [17]. The only difference observed is the presence of a signal at $4.82(2 \mathrm{H}, \mathrm{s})$ and 2.02 of an acetyl group, both signals indicated the oxidation of a methyl group and acetylation and confirmed the presence of 3-methyl-2-butenylacetate side chain. HMBC 
confirmed the structure of the side chain and showed correlations between $\mathrm{H}-8 / \mathrm{C}-10, \mathrm{C}-11, \mathrm{C}-7, \mathrm{C}-3$ and $\mathrm{H}-11 / \mathrm{C}-9, \mathrm{C}-10, \mathrm{C}-8$ and $\mathrm{H}-10 / \mathrm{C}-11, \mathrm{C}-9, \mathrm{C}-8$ and $\mathrm{CO}$ (of the carbonyl group). Other 2D-NMR spectra supported the structure of $\mathbf{1}$ as 1-benzoyl-3(3-methylbut-2-enylacetate)-phloroglucinol, and given the trivial name helinivene $\mathrm{A}$.

Compound $\mathbf{2}$ was obtained as a yellow amorphous powder. The UV spectrum of $\mathbf{2}$, showed $\lambda_{\max }$ at 220, $280 \mathrm{~nm}$. Its IR $(\mathrm{KBr})$ spectrum showed bands of a hydroxyl group $\left(3300 \mathrm{~cm}^{-1}\right)$, terminal $\mathrm{C}=\mathrm{C}$ $\left(3100 \mathrm{~cm}^{-1}\right)$, carbonyl $\left(1800 \mathrm{~cm}^{-1}\right)$, and aromatic $\left(1410 \mathrm{~cm}^{-1}\right)$. HRMS indicated the molecular formula of $\mathrm{C}_{18} \mathrm{H}_{18} \mathrm{O}_{4}$ with $[\mathrm{M}+1]^{+}$at 299.1220 . The NMR of $\mathbf{2}$ is very similar to $\mathbf{1}$ except for the presence of signals of terminal olefinic methylene group at $\delta_{\mathrm{H}} 4.97 \mathrm{~s}, 4.79 \mathrm{~s}\left(\delta_{\mathrm{C}} 110.8,148.8\right)$, and oxygenated methine $\left(\delta_{\mathrm{H}} 4.34 \mathrm{br} \mathrm{d}, J=7.8 \mathrm{~Hz} ; \delta_{\mathrm{C}} 77.7\right)$ and the absence of signals of $\mathrm{H}-8$ (olefinic proton) and $\mathrm{H}-10$ acetylated methylene group (Tables 1 and 2). The above data indicated the presence of 2-hydroxyl-3-methylbut-3-enyl side chain. The HMBC correlations of $\mathbf{2}$ supported the structure as depicted in Figure 1 and showed correlations between H-11/C-9, C-10, C-8; H-8/C-10, C-11, C-3 and H-7/C-3, C-4, C-8, C-9 (among others). Direct correlation of optical rotation value $\left([\alpha]_{D}^{20}-95, c 0.1\right.$ [reported $[\alpha]_{D}^{20}-106(c 0.1)$ ] suggested $S$ configuration of C-8 [18]. The forgoing data established the chemical structure of $\mathbf{2}$ as 1-benzoyl-3(2S-hydroxyl-3-methylbut-3-enyl)-phloroglucinol (helinivene B).

Compound $\mathbf{3}$ was obtained as a pale amorphous powder with similar spectroscopic data of phloroglucinol derivatives like 1 and 2. It showed UV (MeOH) $\lambda_{\max } 314 \mathrm{~nm}$, while IR (KBr) spectrum showed bands of a hydroxyl group $\left(3300 \mathrm{~cm}^{-1}\right)$, and carbonyl $\left(1629 \mathrm{~cm}^{-1}\right)$. The molecular formula of 3 was determined to be $\mathrm{C}_{15} \mathrm{H}_{20} \mathrm{O}_{5}$, which require six degree of unsaturation [ $m / z$ 279.1596]. The NMR data showed signals of 1-methyl-1-propanone side chain (Tables 1 and 2), an aromatic proton at $5.99 \mathrm{~s}$, and two oxygenated carbons at $80.0,69.2$, one of them showed a proton at $\delta_{\mathrm{H}} 3.81$, cyclic methylene group at $\delta_{\mathrm{H}} 2.87,2.51$. The conjugated carbonyl and the aromatic ring accounted for five of the six observed degrees of unsaturation, indicating that the compound contained extra ring. The signals of cyclic methylene, methine and oxygenated carbon suggested the presence of a pyrane moiety. Furthermore, the compound showed similar ${ }^{1} \mathrm{H}-\mathrm{NMR}$ spectra to that of 8-benzoyl-3,5,7-trihydroxy2,2-dimethoxychroman isolated from Leontonyx spathulatus [17]. The only difference is the nature of the side chain at C-8, which showed typical signals of 2-methyl-1-propanone (Tables 1 and 2). The HMBC confirmed the pyrane ring connectivity and the side chain at $\mathrm{C}-8$ and showed correlations between H-4/C-9, C-5, C-10, C-2; H-6/C-5, C-7, C-10, C-1 and H-2'/C-1' and C-8. Other 2D spectra thereby supported the structure of 3 . The absolute configuration at $\mathrm{C}-3$ could not be ascertained directly from the data obtained however, the comparison of the measured specific rotation value $\left([\alpha]_{D}^{20}+1.8,(c 0.04 \mathrm{MeOH})\right]$ of 3 with the reported value [reported $[\alpha]_{D}^{20}-1.2$ (c $\left.0.029, \mathrm{MeOH}\right)$ of similar structure containing "identical stereo centre" and similar coupling constant values of H-3 and H-4 [19] indicated $3 S$ isomer of 3. Accordingly, the structure of $\mathbf{3}$ was established as 8-(2-methyl-1-propanone)-3S,5,7-trihydroxyl2,2-dimethylchromane (helinivene C). 
Table 1. ${ }^{1} \mathrm{H}-\mathrm{NMR}(400 \mathrm{MHz}: m, J \mathrm{~Hz})$ spectral data of compounds $\mathbf{1}-\mathbf{1 0}$ in $\mathrm{CDCl}_{3}(\mathbf{4}, \mathbf{5}, \mathbf{7}$ and $\mathbf{1 0})$ or $\mathrm{CD}_{3} \mathrm{COCD}_{3}(\mathbf{1}-\mathbf{3}, \mathbf{6}, \mathbf{8}, \mathbf{9})$.

\begin{tabular}{|c|c|c|c|c|c|c|c|c|c|c|}
\hline & 1 & 2 & 3 & 4 & 5 & 6 & 7 & 8 & 9 & 10 \\
\hline 1 & - & - & - & - & - & - & - & - & - & - \\
\hline 2 & - & - & - & - & - & - & - & - & - & - \\
\hline 3 & - & - & $3.81 b r \mathrm{t} 6.8$ & $5.91 s$ & $5.91 s$ & - & - & - & - & - \\
\hline 4 & - & - & $\begin{array}{l}2.87 d d(5.5,16.6) \\
2.51 d d(7.7,16.6)\end{array}$ & - & - & - & - & - & - & - \\
\hline 5 & $6.07 s$ & $6.03 s$ & - & $5.91 s$ & $5.91 s$ & $6.05 s$ & $5.83 s$ & - & $6.06 s$ & $5.88 s$ \\
\hline 6 & - & - & $5.99 s$ & - & - & - & - & - & - & - \\
\hline 7 & $3.38 d, 7.5$ & $\begin{array}{l}3.02 d d, 15.8,2.0 \\
2.77 d d, 15.8,7.8\end{array}$ & - & - & - & $3.22 d, 6.5$ & $3.32 d, 7.0$ & $3.45 d, 7.6$ & $3.23 d, 6.8$ & $3.42 d, 7.0$ \\
\hline 8 & $5.54 t, 7.5$ & $4.34 \mathrm{brd}, 7.8$ & - & $3.70 \mathrm{sext}, 6.4$ & 3.83 sept, 6.4 & $5.20 t, 6.5$ & $5.21 t, 7.0$ & $5.51 t, 7.6$ & $5.21 t, 6.8$ & $5.38 t, 7.0$ \\
\hline 9 & - & - & - & $1.38 \mathrm{~m}$ & $1.59 d, 6.4$ & - & - & - & - & - \\
\hline 10 & $4.82 s$ & $4.97 s, 4.79 s$ & - & $1.14 d, 6.4$ & $1.59 d, 6.4$ & $1.61 s$ & $1.73 s$ & $4.82 s$ & $1.73 s$ & $4.73 s$ \\
\hline 11 & $1.71 s$ & $1.81 s$ & $1.37 s$ & $0.89 t, 7.6$ & - & $1.72 s$ & $1.78 \mathrm{~s}$ & $1.71 *$ & $1.62 s$ & $1.70 \mathrm{~s}$ \\
\hline 12 & - & - & $1.45 s$ & - & - & - & - & - & - & - \\
\hline $1^{\prime}$ & - & - & - & $4.47 d, 6.7$ & $4.47 d, 6.7$ & - & - & - & - & - \\
\hline $2^{\prime}$ & - & - & 3.92 sept 6.7 & $5.42 t, 6.7$ & $5.42 t, 6.7$ & $3.04 t, 7.4$ & 3.74 sext, 6.8 & $3.08 t, 7.2$ & 3.98 sept, 6.8 & 3.89 sept, 6.8 \\
\hline $3^{\prime}$ & $7.59 \mathrm{~m}$ & 7.49 br. d, 7.2 & $1.15 d 6.7$ & - & - & $1.67 \mathrm{sext}, 7.4$ & $1.37 \mathrm{~m}$ & $1.71 *$ & $1.12 \mathrm{~s}$ & $1.43 \mathrm{~s}$ \\
\hline $4^{\prime}$ & $7.38 \mathrm{~m}$ & $7.40 \mathrm{br} . t, 7.6$ & $1.15 d 6.7$ & $1.77 \mathrm{~s}$ & $1.77 s$ & $0.94 t, 7.4$ & $0.88 t, 7.2$ & $0.99 t, 7.2$ & $1.12 s$ & $1.43 s$ \\
\hline $5^{\prime}$ & $7.47 \mathrm{~m}$ & 7.45 br t, 7.6 & & $1.71 s$ & $1.71 \mathrm{~s}$ & - & $1.13 d, 6.8$ & - & - & - \\
\hline $6^{\prime}$ & $7.38 \mathrm{~m}$ & $7.40 \mathrm{br} . t, 7.6$ & - & - & - & - & - & - & - & - \\
\hline $7^{\prime}$ & $7.59 \mathrm{~m}$ & $7.49 b r . d, 7.2$ & - & - & - & - & - & - & - & - \\
\hline $\mathrm{COCH}_{3}$ & $2.02 \mathrm{~s}$ & - & - & - & - & - & - & $2.07 \mathrm{~s}$ & - & $2.05 \mathrm{~s}$ \\
\hline $2-\mathrm{OH}$ & $12.27 s$ & - & - & - & $9.92 s$ & $14.07 s$ & $11.76 s$ & $14.0 \mathrm{~s}$ & $14.09 s$ & $12.88 s$ \\
\hline $4-\mathrm{OH}$ & $9.28 s$ & - & - & - & - & $9.31 \mathrm{brs}$ & $8.81 \mathrm{brs}$ & $9.66 b r s$ & $9.33 \mathrm{brs}$ & $8.23 \mathrm{brs}$ \\
\hline $6-\mathrm{OH}$ & $8.99 \mathrm{~s}$ & - & - & - & $9.92 s$ & - & - & $9.25 \mathrm{brs}$ & - & - \\
\hline
\end{tabular}


Table 2. ${ }^{13} \mathrm{C}$-NMR spectral data of compounds $\mathbf{1}-\mathbf{1 0}$ in $\mathrm{CDCl}_{3}(\mathbf{4}, \mathbf{5}, \mathbf{7}$ and $\mathbf{1 0})$ or $\mathrm{CD}_{3} \mathrm{COCD}_{3}(\mathbf{1}-\mathbf{3}, \mathbf{6}, \mathbf{8}, \mathbf{9})$.

\begin{tabular}{ccccccccccc}
\hline & $\mathbf{1}$ & $\mathbf{2}$ & $\mathbf{3}$ & $\mathbf{4}$ & $\mathbf{5}$ & $\mathbf{6}$ & $\mathbf{7}$ & $\mathbf{8}$ & $\mathbf{9}$ & $\mathbf{1 0}$ \\
\hline 1 & $104.5 s$ & $104.9 s$ & - & $104.5 s$ & $104.0 s$ & $105.1 s$ & $105.7 s$ & $105.4 s$ & $104.3 s$ & $104.0 s$ \\
2 & $163.4 s$ & $163.2 s$ & $27.1 s$ & $164.6 s$ & $164.7 s$ & $165.2 s$ & $162.6 s$ & $165.4 s$ & $165.2 s$ & $163.5 s$ \\
3 & $106.4 s$ & $106.5 s$ & $80.0 d$ & $95.1 d$ & $95.1 d$ & $107.9 s$ & $104.7 s$ & $107.0 s$ & $108.0 s$ & $105.8 s$ \\
4 & $163.2 s$ & $161.2 s$ & $69.2 t$ & $164.6 s$ & $164.7 s$ & $160.5 s$ & $159.9 s$ & $162.8 s$ & $162.5 s$ & $160.7 s$ \\
5 & $96.0 d$ & $96.6 d$ & $157.2 s$ & $95.1 d$ & $95.1 d$ & $95.0 d$ & $95.4 d$ & $95.3 d$ & $95.1 d$ & $95.3 d$ \\
6 & $160.0 s$ & $160.1 s$ & $163.4 s$ & $164.6 s$ & $164.7 s$ & $162.6 s$ & $160.7 s$ & $161.1 s$ & $160.1 s$ & $159.4 s$ \\
7 & $21.91 t$ & $28.9 t$ & $167.0 s$ & $210.1 s$ & $210.2 s$ & $22.0 t$ & $21.6 t$ & $22.1 t$ & $22.1 t$ & $21.0 t$ \\
8 & $129.2 d$ & $77.7 d$ & $105.6 s$ & $45.9 d$ & $39.3 d$ & $124.3 d$ & $121.6 d$ & $129.6 d$ & $124.2 d$ & $128.9 d$ \\
9 & $130.4 s$ & $148.8 s$ & $96.6 s$ & $26.9 t$ & $19.2 q$ & $130.8 s$ & $135.9 s$ & $130.4 s$ & $130.8 s$ & $129.9 s$ \\
10 & $63.7 t$ & $110.8 t$ & $100.6 s$ & $11.9 q$ & $19.2 q$ & $26.0 q$ & $25.8 q$ & $64.0 t$ & $17.9 q$ & $64.1 t$ \\
11 & $21.6 q$ & $19.0 q$ & $20.3 q$ & $16.6 q$ & - & $17.9 q$ & $17.9 q$ & $21.8 q$ & $25.9 q$ & $21.1 q$ \\
12 & - & - & $20.2 q$ & - & - & - & - & - & - & - \\
$1^{\prime}$ & $200.3 s$ & $200.1 s$ & $211.1 s$ & $65.1 t$ & $65.1 t$ & $206.5 s$ & $210.8 s$ & $206.9 s$ & $210.9 s$ & $210.8 s$ \\
$2^{\prime}$ & $143.0 s$ & $143.4 s$ & $40.3 d$ & $118.7 d$ & $118.7 d$ & $46.5 t$ & $45.9 d$ & $46.8 t$ & $39.7 d$ & $39.2 d$ \\
$3^{\prime}$ & $128.4 d$ & $128.9 d$ & $26.1 q$ & $139.2 s$ & $139.2 s$ & $19.0 t$ & $26.9 t$ & $19.2 t$ & $19.8 q$ & $19.3 q$ \\
$4^{\prime}$ & $129.1 d$ & $129.6 d$ & $21.1 q$ & $18.2 q$ & $18.2 q$ & $14.4 q$ & $11.9 q$ & $14.6 q$ & $19.8 q$ & $19.3 q$ \\
$5^{\prime}$ & $131.6 d$ & $132.4 d$ & - & $25.8 q$ & $25.8 q$ & - & $16.9 q$ & - & - & - \\
$6^{\prime}$ & $129.1 d$ & $129.6 d$ & - & - & - & - & - & - & - & - \\
$7^{\prime}$ & $128.4 d$ & $128.9 d$ & - & - & - & - & - & - & - & - \\
$\mathrm{CO}^{\prime}$ & $171.3 s$ & - & - & - & - & - & - & $171.5 s$ & -- & $172.6 s$ \\
$\mathrm{CH}_{3}$ & $20.9 q$ & - & - & - & - & - & - & $21.1 q$ & - & $21.2 q$ \\
\hline & & & & & & & & & &
\end{tabular}


Compounds 4 and 5 showed very similar NMR spectra. ${ }^{1} \mathrm{H}-\mathrm{NMR}$ showed signals of two aromatic protons at $\delta_{\mathrm{H}} 5.91 \mathrm{~s}$, and a typical signal of $O$-prenyl group. The only difference between $\mathbf{4}$ and $\mathbf{5}$ is the side chain at $\mathrm{C}-1$; in the case of $\mathbf{4},{ }^{1} \mathrm{H}-\mathrm{NMR}$ showed a typical 2-methylbutanone, while $\mathbf{5}$ showed 2-methylpropanone. 4 was identified as 1-(2-methylbutanone)-4- $O$-prenyl-phloroglucinol and $\mathbf{5}$ as 1-(2-methylpropanone)-4-O-prennyl-phloroglucinol. Both 4 and 5 were previously isolated from H. crispum [20]. 6 showed a typical NMR signals like that of 1-(butanone)-3-prenyl-phloroglucinol [21], while 7 identified as 1-(2-methylbutanone)-3-prenyl-phloroglucinol. Compounds 6 and 7 were isolated previously from H. gymnoconum [22]. Compound 8 was identified as 1-butanone-3-(3-methylbut-2enylacetate)-phloroglucinol [21], 9 was identified as 1-(2-methylpropanone)-3-prenylphloroglucinol and previously isolated from $H$. mimetes [23] and $\mathbf{1 0}$ identified as caespitate, was first isolated from H. caespititium [23].

Compound 11 was obtained as a white solid and is the only alcohol triterpene detected in this study. 11 was identified as 33-24-dihydroxyterexer-14-ene and reported previously from Erythroxylum passerium [24]. According to SciFinder and the dictionary of natural products, the occurrence of 11 from Helichrysum species is reported for the first time.

\subsection{Total Antioxidant Capacities of Acylphloroglucinols}

The greater the number of hydroxyl groups in phenolic compounds, the higher is the antioxidant activity. Hydroxyl radicals are an extremely reactive oxygen species, capable of modifying almost every molecule in the living cell. Moreover, hydroxyl radicals are capable of quick initiation of the lipid peroxidation process by abstracting hydrogen atoms from unsaturated fatty acids [25].

The total antioxidant capacities of a methanolic extract (HF) and its isolated compounds (1-11) were evaluated using a battery of assays which included the FRAP, ORAC, TEAC and $\mathrm{Fe}^{2+}$-induced microsomal lipid peroxidation assays. Helinivenes A and B (1 and 2) when compared to EGCG, displayed significantly higher $\mathrm{ORACOH}$ values $(64.85 \pm 10.95 ; 94.97 \pm 5.88 v s .3 .91 \pm 4.65) \times 10^{6} \mu \mathrm{M} \mathrm{TE} / \mathrm{g}$, respectively. The same trend of significantly increased capacity for $\mathbf{1}$ and $\mathbf{2}$ than EGCG when using the peroxyl radical absorbance capacity assay was observed $(22,671.78 \pm 26.72 ; 45,095.82 \pm 31.99 v s$. $14,693.0 \pm 5.53) \mu \mathrm{M}$ TE/g respectively, while compounds 6-10 showed a mild peroxyl absorbance capacity (range 13,544-16,735 $\mu \mathrm{M} \mathrm{TE} / \mathrm{g}$ ), and hydroxyl absorbance capacity (range 16.26-24.24) $\times$ $10^{6} \mu \mathrm{M} \mathrm{TE} / \mathrm{g}$, respectively, as shown in Table 3 .

The findings corroborate that of previous reports on the structure-activity relationship of antioxidant activities of monomeric phenolic compounds, prenylated coumarins and phloroglucinol derivatives, where their respective antioxidant activities were found to depend on the degree of hydroxylation and extent of conjugation [25-27]. The potential antioxidant activities of $\mathbf{1}$ and $\mathbf{2}$, as well as moderate antioxidant activities demonstrated by 6-10 may be attributed to the presence of hydroxyl groups, which act as good hydrogen donors, thereby forming phenolate ions as intermediates. These intermediates are stabilized by resonance when unpaired electrons at the $m$-positions of the aromatic ring are delocalized [26]. To further elucidate the mechanism of action of the isolated compounds, we established whether the isolated compounds have the ability of transferring electrons to free radicals by measuring their FRAP and TEAC activities at different $\mathrm{pH}$. The results in Table 3 shows, as expected, that phloroglucinols containing aromatic acyl groups (1 and 2) possessed higher antioxidant (when measured 
as FRAP, TEAC) activities relative to their monocyclic (4-10), and bicyclic (3) counterparts with aliphatic acyl substitutions. The observed tendencies demonstrated by these compounds are in accordance with data previously reported in the literature [27,28]. It is evident therefore that the isolated compounds $\mathbf{1}$ and $\mathbf{2}$ possessed interesting antioxidant activities, expressed as their trolox (TEAC, ORAC) and ascorbic acid (FRAP) equivalents.

Table 3. Total antioxidant capacities of a methanolic extract of $H$. niveum and its constituents.

\begin{tabular}{ccccccc}
\hline Sample & Peroxyl & $\begin{array}{c}\text { Hydroxyl } \times \\
\mathbf{1 0}^{\mathbf{6}} \boldsymbol{\mu M T E} \mathbf{g} *\end{array}$ & Prooxidant & TEAC & FRAP $\boldsymbol{\mu M A A E} / \mathbf{g} *$ & $\begin{array}{c}\text { Anti-Lipid peroxidation } \\
\text { IC } \mathbf{5 0} ;(\boldsymbol{\mu g} / \mathbf{m L}) * *\end{array}$ \\
\hline HF *** & $4553.13 \pm 17.77$ & $53.77 \pm 8.42$ & $17.29 \pm 0.99$ & $1449.54 \pm 3.09$ & $437.64 \pm 6.86$ & $27.73 \pm 4.00$ \\
$\mathbf{1}$ & $22671.78 \pm 26.72$ & $64.85 \pm 10.95$ & $8.92 \pm 1.15$ & $19545.00 \pm 10.25$ & $2530.54 \pm 0.92$ & $5.12 \pm 0.90$ \\
$\mathbf{2}$ & $45095.82 \pm 31.99$ & $94.97 \pm 5.88$ & $756.90 \pm 1.98$ & $43615.73 \pm 6.66$ & $4950.08 \pm 0.65$ & $3.55 \pm 1.92$ \\
$\mathbf{3}$ & $3937.78 \pm 25.85$ & $5.99 \pm 4.52$ & $41.73 \pm 8.20$ & $6001.40 \pm 5.63$ & $155.65 \pm 12.02$ & $>50.00$ \\
$\mathbf{4}$ & $5406.65 \pm 1.39$ & $3.92 \pm 14.47$ & $7.02 \pm 4.02$ & $1629.10 \pm 2.03$ & $194.27 \pm 1.78$ & $44.62 \pm 2.08$ \\
$\mathbf{5}$ & $6053.87 \pm 18.67$ & $5.60 \pm 0.79$ & $12.33 \pm 6.62$ & $2673.62 \pm 1.68$ & $446.64 \pm 8.07$ & $20.22 \pm 2.72$ \\
$\mathbf{6}$ & $13544.93 \pm 12.13$ & $18.07 \pm 3.47$ & $64.37 \pm 0.22$ & $4316.61 \pm 1.06$ & $1183.52 \pm 6.20$ & $30.80 \pm 2.12$ \\
$\mathbf{7}$ & $14139.74 \pm 5.96$ & $23.12 \pm 18.94$ & $73.87 \pm 1.10$ & $9998.71 \pm 2.66$ & $1029.03 \pm 0.66$ & $27.49 \pm 3.19$ \\
$\mathbf{8}$ & $14218.17 \pm 12.36$ & $16.70 \pm 1.25$ & $76.59 \pm 0.27$ & $6757.40 \pm 4.69$ & $1203.02 \pm 2.07$ & $27.56 \pm 0.63$ \\
$\mathbf{9}$ & $13639.27 \pm 17.62$ & $24.24 \pm 1.71$ & $69.54 \pm 0.29$ & $4423.32 \pm 3.11$ & $1096.01 \pm 1.12$ & $20.95 \pm 2.62$ \\
$\mathbf{1 0}$ & $16735.55 \pm 21.72$ & $16.26 \pm 15.39$ & $92.31 \pm 1.59$ & $8705.14 \pm 1.83$ & $1019.28 \pm 1.79$ & $20.50 \pm 4.01$ \\
$\mathbf{1 1}$ & $1193.10 \pm 1.68$ & $0.89 \pm 7.34$ & $31.38 \pm 7.00$ & $1323.61 \pm 1.76$ & $197.99 \pm 3.90$ & $>50.00$ \\
EGCG & $14970.09 \pm 5.53$ & $3.91 \pm 4.65$ & $6.48 \pm 1.19$ & $11545.44 \pm 17.28$ & $3326.45 \pm 5.76$ & $1.04 \pm 1.02$ \\
\hline
\end{tabular}

$*$ Data expressed as $\pm \% \mathrm{STDEV}$; ** Data are given as $\mathrm{IC}_{50} \pm \mathrm{STDEV}$ with tested samples screened at $50.00 \mu \mathrm{g} / \mathrm{mL}$; HF ***: methanolic extract of H. niveum.

Over production of ROS results in an attack of not only DNA, but also other important cellular components, including the polyunsaturated fatty acids (PUFAs) in cell membranes, which are highly susceptible to free-mediated oxidation [29]. Compounds $\mathbf{1}$ and $\mathbf{2}$ demonstrated a potent inhibitory activity against the $\mathrm{Fe}^{2+}$-induced lipid peroxidation $\left(\mathrm{IC}_{50}=5.12 \pm 0.90 ; 3.55 \pm 1.92\right) \mu \mathrm{g} / \mathrm{mL}$, respectively (Table 3) in a competitive manner to that of EGCG ( $\left.\mathrm{IC}_{50} 1.04 \pm 1.02\right) \mu \mathrm{g} / \mathrm{mL}$. This result is in agreement with previous work, where phloroglucinol were found to possess similar $\mathrm{Fe}^{2+}$-induced inhibition against lipid peroxidation to that of BHA and $\alpha$-tocopherol [30]. Our observations further explain how the poly-hydroxylated ring A of $\mathbf{1}$ and $\mathbf{2}$ can be an active "anti-lipid peroxidation skeleton". However, it is possible that the second aromatic ring in $\mathbf{1}$ and $\mathbf{2}$ can enhance the contact of these antioxidants with lipids, and consequently resulting in an efficient termination of the chain reaction [31].

\subsection{The Skin Aging Related-Enzymes Inhibitory Activities of Acylphloroglucinols}

The methanolic extract (HF) and the isolated compounds 1-11 were evaluated for their anti-tyrosinase activity at the optimum concentration of $100 \mu \mathrm{g} / \mathrm{mL}$. Moderate inhibition of tyrosinase activity demonstrated by these compounds (specifically $\mathbf{1}$ and $\mathbf{2}$, as indicated in Table 4), might depend on the substitution pattern of the hydroxyl groups and non-existence of the catechol group, which may form hydrogen bonds to a chelating site of the enzyme [32,33]. 
Further attempts were made to correlate the chemistry of phenol-metal chelation between $\mathrm{Fe}^{2+}$ (in lipid peroxidation assay) to that of $\mathrm{Cu}^{2+}$ (in tyrosinase assay), but the anti-tyrosinase result indicated that kojic acid is eight times more active than $\mathbf{1}$ and $\mathbf{2}$. We therefore proposed that the mechanism of $\mathrm{Fe}^{2+}$ chelation in the lipid peroxidation assay may be totally different from that of $\mathrm{Cu}^{2+}$ chelation in the tyrosinase assay, despite both metal ions $\left(\mathrm{Fe}^{2+}\right.$ and $\left.\mathrm{Cu}^{2+}\right)$ being bivalent in nature. The results obtained in Table 4 demonstrated a less potent inhibition against elastase (with $\mathrm{IC}_{50}$ ranged 25.31-69.61 $\mu \mathrm{g} / \mathrm{mL}$ ), in comparison to oleanolic acid ( $\mathrm{IC}_{50} 10.08 \pm 8.47 \mu \mathrm{g} / \mathrm{mL}$ ). No scientific report has pointed out the reason for such activity, except previous data indicating a less potent activity of the non-prenylated acylphloroglucinol against inhibition of the release of leukocyte elastase [34]. None of the compounds demonstrated activity against acetylcholinesterase except at a high concentration of $250.00 \mu \mathrm{g} / \mathrm{mL}$, possibly due to the absence of nitrogen atom-containing compounds in our isolated products [35].

Table 4. Enzyme inhibitory effect of a methanolic extract of $H$. niveum and its constituents.

\begin{tabular}{cccc}
\hline Sample & \multicolumn{3}{c}{ Inhibitory Activities $\left(\mathbf{I C}_{\mathbf{5 0}} \mathbf{\pm} \% \mathbf{\text { STDEV}} \boldsymbol{\mu \boldsymbol { g }} / \mathbf{m L}\right)$} \\
\hline & Tyrosinase & Elastase & Acetylcholinesterase \\
\hline HF $^{* *}$ & $76.02 \pm 4.91$ & $92.97 \pm 8.90$ & $257.98 \pm 4.01$ \\
$\mathbf{1}$ & $35.63 \pm 4.67$ & $>100.00$ & $267.96 \pm 3.88$ \\
$\mathbf{2}$ & $26.72 \pm 5.05$ & $>100.00$ & $267.96 \pm 1.15$ \\
$\mathbf{3}$ & $80.31 \pm 3.31$ & $25.31 \pm 7.85$ & $272.95 \pm 4.61$ \\
$\mathbf{4}$ & $>100.00$ & $45.63 \pm 15.27$ & $272.95 \pm 1.67$ \\
$\mathbf{5}$ & $>100.00$ & $69.61 \pm 4.71$ & $252.99 \pm 2.41$ \\
$\mathbf{6}$ & $>100.00$ & $35.47 \pm 7.85$ & $252.99 \pm 2.13$ \\
$\mathbf{7}$ & $>100.00$ & $66.72 \pm 5.21$ & $260.48 \pm 5.04$ \\
$\mathbf{8}$ & $>100.00$ & $63.44 \pm 7.56$ & $248.00 \pm 5.41$ \\
$\mathbf{9}$ & $>100.00$ & $61.563 \pm 4.69$ & $25050 \pm 2.49$ \\
$\mathbf{1 0}$ & $>100.00$ & $58.75 \pm 5.42$ & $250.50 \pm 2.21$ \\
$\mathbf{1 1}$ & $>100.00$ & $>100.00$ & $313.19 \pm 4.58$ \\
Kojic acid & $3.51 \pm 6.01$ & - & - \\
Oleanolic acid & - & $10.08 \pm 8.47$ & - \\
Galanthamine & - & - & $10.98 \pm 1.03$ \\
\hline
\end{tabular}

* Data are given as IC50 \pm STDEV with tested samples screened at $100.00 \mu \mathrm{g} / \mathrm{mL}$ for anti-tyrosinase anti-elastase assays, while $500.00 \mu \mathrm{g} / \mathrm{mL}$ was considered as upper concentration limits for acetylcholinesterase assay. HF **: Methanolic extract of $H$. niveum.

\section{Experiment Section}

\subsection{Chemicals and Reagents}

The organic solvents methanol, acetonitrile (HPLC graded), ethanol, ethyl acetate, dichloromethane, hexane (technical grade), deuterated chloroform and acetone were supplied by Merck (Cape Town, South Africa). Sulfuric acid and acetic acid were secured from Kimix (Cape Town, South Africa). Kojic acid, galanthamine, oleanolic acid, epigallocatechin gallate (EGCG), trolox (6-Hydroxyl-2,5,7,8tetramethylchroman-2-carboxylic acid), ABTS (2,2'-Azino-bis (3-ethylbenzo thiazoline-6-sulfonic acid) diammonium salt), 5,5'-dithiobis-(2-nitrobenzoic acid (DTNB), acetythiocholine iodide (ACTI), potassium peroxodisulfate, fluorescein sodium salt, AAPH (2,2'-Azobis (2-methylpropionamidine) dihydrochloride, perchloric acid, TPTZ (2,4,6-tri[2-pyridyl]-S-triazine, Iron (III) chloride hexahydrate, 
tris- $\mathrm{HCl}$, sepharose (wet bead diameter, 60-200 $\mu \mathrm{m}$ ), copper sulfate, hydrogen peroxide, and $N$-succ(Ala)3-nitroanilide (SANA) were secured from Sigma-Aldrich, Inc. (St. Louis, MO, USA).

\subsection{Plant Material}

The aerial parts of the plant were collected in October 2012, from Jonkershoek (about $9 \mathrm{~km} \mathrm{SE}$ Stellenbosch) nature reserve, Western Cape, South Africa. The plant was kindly identified by Dr. Christopher Cupido (SANBI, Kirstenbosch). A voucher specimen (Herbarium number NBG1458801) was deposited at the Compton Herbarium, South African National Biodiversity Institute (SANBI), Kirstenbosch, South Africa.

\subsection{Apparatus}

Preparative HPLC: Preparative HPLC of sample purification was performed on an Agilent Technologies (Santa Clara, CA, USA) 1200 series, equipped with UV detector, manual injector, quaternary pump, vacuum degasser, column compartment (all experiments were done at room temperature) and reversed phase $\mathrm{C} 18$ column SUPELCO $(25 \times 1.0 \mathrm{~cm})$. The flow rate was set at $1.5 \mathrm{~mL} / \mathrm{min}$ and detection wavelength at $254 \mathrm{~nm}$.

Open-Column Liquid Chromatography and Thin-Layer Chromatography: Liquid chromatography (CC) was performed over silica gel $60(0.040-0.063 \mathrm{~mm}$ particle size, Merck, Cape Town, South Africa) and sephadex LH-20 (Sigma-Aldrich, Cape Town, South Africa) as stationary phases, supported with glass column of different diameters. Pre-coated plates of silica gel $60 \mathrm{~F}_{254}$ (Merck, Germany) were used for TLC analysis. Chemical profiles of the fractions were identified based on the color produced after viewing under UV and then spraying with the detecting reagent (vanillin/sulfuric acid) [36].

Optical Rotation: Optical activity measurements were conducted in methanol using a Autopol III Polarimeter (Rudolph research analytical, Hackettstown, MA, USA).

The NMR Analyses: ${ }^{1} \mathrm{H}$ - and ${ }^{13} \mathrm{C}$-NMR spectra were recorded at $25^{\circ} \mathrm{C}$, using deuterated chloroform or acetone on a Bruker Avance $400 \mathrm{MHz}$ NMR spectrometer (Bruker, Rheinstetten, Germany). Chemical shifts of ${ }^{1} \mathrm{H}\left(\delta_{\mathrm{H}}\right)$ and ${ }^{13} \mathrm{C}\left(\delta_{\mathrm{C}}\right)$ were reported in parts per million $(\mathrm{ppm})$ relative to internal reference $\left(\mathrm{CDCl}_{3} ; 7.24 / 77.0 ; \mathrm{CD}_{3} \mathrm{COCD}_{3} ; 2.05 / 206.68\right)$.

In Vitro Biological Activity Measurements: All antioxidant assays including ferric-ion reducing antioxidant power (FRAP), trolox equivalent absorbance capacity (TEAC), lipid peroxidation, and enzyme inhibition (tyrosinase, elastase and acetylcholineesterase) assays were measured using a Multiskan spectrum plate reader, while the automated ORAC assay was read on a Fluoroskan spectrum plate reader. Greiner ${ }^{\circledR}$ F Bottom (white and black) 96-well micro-plates (Greiner Bio-One GmbH, Frickenhausen, Germany) were used for all biological assays of antioxidant and enzymes inhibitory activity.

\subsection{Preparation of Crude Extract}

The aerial parts (stem, leave and flower; $400 \mathrm{~g}$ ) were air dried at room temperature, blended and extracted with methanol $(2.5 \mathrm{~L} \times 2)$ at room temperature $\left(25^{\circ} \mathrm{C}\right)$ for $48 \mathrm{~h}$. The methanol extract was evaporated till dryness under reduced pressure at $40{ }^{\circ} \mathrm{C}$ to yield $15.0 \mathrm{~g}(3.75 \%)$. 


\subsection{Fractionation and Isolation of Constituents Using Semi-Prep HPLC}

The total extract ( $15 \mathrm{~g})$ was applied to a silica gel column and eluted using a gradient of hexane:ethyl acetate: methanol in the order of increasing polarity which resulted in 48 fractions ( $500 \mathrm{~mL}$ each). Fractions collected were combined according to their thin layer chromatographic (TLC) profiles to yield seventeen main fractions labeled I-XVII.

The main fraction XI (1.6 g) was chromatographed on a silica gel column using a gradient of hexane:ethyl acetate (1:0-1:1) (v/v). Sub fraction XI-6 (340 mg) was re-chromatographed on Sephadex using 5\% aq. ethanol and sub-fractions obtained were injected into the HPLC using a gradient of acetonitrile and de-ionized water (60:40 to $80 \%$ acetonitrile in $30 \mathrm{~min}$, then $100 \%$ for $10 \mathrm{~min}$ ) producing three compounds 1 ( $\mathrm{R}_{\mathrm{t}} 25 \mathrm{~min}, 29 \mathrm{mg}, 0.0073 \%$ ), 5 ( $\mathrm{R}_{\mathrm{t}} 34 \mathrm{~min}, 31 \mathrm{mg}, 0.0075 \%$ ) and 6 (Rt $37 \mathrm{~min}, 29 \mathrm{mg}$, $0.0073 \%)$. Sub fraction XI-7 (180 mg) was chromatographed on Sephadex using 5\% aqueous ethanol, with HPLC (75:25 to 90\% acetonitrile in $30 \mathrm{~min}$, then $100 \%$ for $10 \mathrm{~min}$ ) producing 3 ( $\mathrm{R}_{\mathrm{t}} 17 \mathrm{~min}, 44 \mathrm{mg}$, 0.011\%). Main fraction IX (305 mg) was chromatographed on Sephadex using 5\% aqeuous ethanol, then injected into the HPLC (60:40 to $80 \%$ acetonitrile in $30 \mathrm{~min}$, then $100 \%$ for $10 \mathrm{~min}$ ) producing 4 ( $\mathrm{R}_{\mathrm{t}} 35 \mathrm{~min}, 23 \mathrm{mg}, 0.0058 \%$ ). Main fraction VII (2.6 g) was chromatographed on silica gel column using a gradient elution of hexane: ethyl acetate 100:0 to 7:3 (v/v). Sub fractions VII-5 (72 mg) was injected to the HPLC (70:30 to $90 \%$ acetonitrile in $20 \mathrm{~min}$, then $100 \%$ for $15 \mathrm{~min}$ ) producing two compounds as 7 ( $\mathrm{R}_{\mathrm{t}} 22 \mathrm{~min}, 17 \mathrm{mg}, 0.0043 \%$ ), and 9 ( $\mathrm{R}_{\mathrm{t}} 25 \mathrm{~min}, 24 \mathrm{mg}, 0.006 \%$ ). Main fraction VI (200 mg) was chromatographed on sephadex using 5\% aqueous ethanol, then injected into the HPLC (80:20 to $90 \%$ acetonitrile in $20 \mathrm{~min}$, then $100 \%$ for $15 \mathrm{~min}$ ) producing compound 8 ( $\mathrm{R}_{\mathrm{t}} 23 \mathrm{~min}, 21 \mathrm{mg}$, $0.0053 \%)$. Main fraction III (130 mg) was chromatographed on Sephadex using 5\% aqueous ethanol, then injected into the HPLC (75:25 to $90 \%$ acetonitrile in $30 \mathrm{~min}$, then 100\% for $10 \mathrm{~min}$ ) producing two compounds as 10 ( $\mathrm{R}_{\mathrm{t}} 22 \mathrm{~min}, 13 \mathrm{mg}, 0.0033 \%$ ), and $\mathbf{2}\left(\mathrm{R}_{\mathrm{t}} 28 \mathrm{~min}, 15 \mathrm{mg}, 0.0038 \%\right.$ ). Main fraction IV $(155 \mathrm{mg})$ was chromatographed on a Sephadex column using 5\% aqueous ethanol producing compound 11 (53 mg, 0.0133\%).

\subsection{Structural Identification of Compounds}

All compounds were identified based on extensive spectroscopic data analyses, including one-dimensional ( ${ }^{1} \mathrm{H}-$ and ${ }^{13} \mathrm{C}-$ ) and two-dimensional NMR (HSQC, HMBC and NOESY).

\subsection{Total Antioxidant Capacity Assays}

Ferric-Ion Reducing Antioxidant Power (FRAP) Assay: Working FRAP reagent was prepared in accordance to the method described previously [37]. Absorbance was measured at $593 \mathrm{~nm}$. L-ascorbic acid was used as a standard and the results were expressed as $\mu \mathrm{M}$ ascorbic acid equivalents per milligram dry weight ( $\mu \mathrm{M}$ AAE/g DW) of the test samples.

Automated Oxygen Radicals Absorbance Capacity (ORAC) Assay: ORAC was measured according to the method previously described [16]. The method measures the antioxidant scavenging capacity for (a) peroxyl radicals generated by thermal decomposition of 2,2'-azobis (2-aminopropane) dihydrochloride (AAPH; ORACROo assay); (b) hydroxyl radical (ORACoH assay), generated by $\mathrm{H}_{2} \mathrm{O}_{2}-\mathrm{Cu}^{2+}\left(\mathrm{H}_{2} \mathrm{O}_{2}, 0.3 \%\right.$; $\mathrm{Cu}^{2+}$ [as $\left.\mathrm{CuSO}_{4}\right], 18 \mu \mathrm{M}$, or (c) $\mathrm{Cu}^{2+}$ [as $\mathrm{CuSO}_{4}$ ], $18 \mu \mathrm{M}$ as a transition metal 
oxidant at $37^{\circ} \mathrm{C}$. ORAC values were expressed as micromoles of trolox equivalents (TE) per milligram of test sample, except when $\mathrm{Cu}^{2+}$ (without $\mathrm{H}_{2} \mathrm{O}_{2}$ ) was used as an oxidant in the assay. In the presence of $\mathrm{Cu}^{2+}$ without $\mathrm{H}_{2} \mathrm{O}_{2}$, test samples acted as prooxidants rather than antioxidants in the ORAC assay. The copper-initiated prooxidant activity was calculated using [(AreaBlank - Areasample)/AreaBlank] $\times 100$ and expressed as prooxidant units; one unit equals the prooxidant activity that reduces the area under the fluorescein decay curve by $1 \%$ in the ORAC assay.

Trolox Equivalent Absorbance Capacity (TEAC) Assay: The total antioxidant capacity of the test samples in terms of TEAC were measured using a previously described method [38]. Absorbance was read at $734 \mathrm{~nm}$ at $25{ }^{\circ} \mathrm{C}$ in a plate reader and the results were expressed as $\mu \mathrm{M}$ trolox equivalents per milligram dry weight ( $\mu \mathrm{M}$ TE/g DW) of the test samples.

Inhibition of Fe (II)-Induced Microsomal Lipid Peroxidation Assay: The thiobarbituric acid reactive substances (TBARs) method was used to evaluate the inhibition of lipid peroxidation as previously described [39] with minor adjustment. Rat liver microsomes were isolated from an S9 fraction using a Sepharose column with $0.01 \mathrm{M}$ potassium phosphate buffer; $\mathrm{pH} 7.4$, supplemented with $1.15 \% \mathrm{KCl}$ at $5{ }^{\circ} \mathrm{C}$. Absorbance was measured at $532 \mathrm{~nm}$ and the percentage inhibition of TBARs formation relative to the positive control was recorded.

\subsection{Enzyme Inhibition Assays}

Tyrosinase Enzyme Assay: The tyrosinase inhibitory activity was measured using the spectrophotometric method previously described [16]. Samples were dissolved in DMSO to a stock solution of $1 \mathrm{mg} / \mathrm{mL}$, and further dilutions were then done with $50 \mathrm{mM}$ sodium phosphate buffer (pH 6.5) for all working solutions. Kojic acid was used as control drug. In the wells of a 96-well plate, $70 \mu \mathrm{L}$ of each sample working solution was combined with $30 \mu \mathrm{L}$ of tyrosinase $(500 \mathrm{Units} / \mathrm{mL}$ in sodium phosphate buffer) in triplicate. After incubation at room temperature for $5 \mathrm{~min}, 110 \mu \mathrm{L}$ of substrate ( $2 \mathrm{mM}$ L-Tyrosine) was added to each well. Final concentrations of the crude extract, isolated compounds, and positive control ranged from 1.0-100 $\mu \mathrm{g} / \mathrm{mL}$. Incubation commenced for $30 \mathrm{~min}$ at room temperature and the enzyme activity was determined by measuring the absorbance at $490 \mathrm{~nm}$. The percentage of tyrosinase inhibition was calculated as follows:

$$
\text { Tyrosinase inhibition }(\%)=[(\mathrm{A}-\mathrm{B})-(\mathrm{C}-\mathrm{D})] /(\mathrm{A}-\mathrm{B}) \times 100
$$

where $\mathrm{A}$ is the absorbance of the control with the enzyme, $\mathrm{B}$ is the absorbance of the control without the enzyme, $\mathrm{C}$ is the absorbance of the test sample with the enzyme and $\mathrm{D}$ is the absorbance of the test sample without the enzyme.

Elastase Inhibition Assay: Inhibition of elastase by the test samples was assayed using $N$-succyl-(Ala)-3-nitroanilide (SANA) as the substrate, monitoring the release of $p$-nitroanilide by the method described previously [16]. The inhibitory activity determined the intensity of color released during cleavage of SANA by the action of elastase. Briefly, $1 \mathrm{mM}$ SANA was prepared in $0.1 \mathrm{M}$ Tris- $\mathrm{HCl}$ buffer $\mathrm{pH} 8.0$ and $200 \mu \mathrm{L}$ of this solution was added to the $20 \mu \mathrm{L}$ of sample solution in a 96-Well plate. The mixtures were vortexed and preincubated for $10 \mathrm{~min}$ at $25^{\circ} \mathrm{C}$ and then $20 \mu \mathrm{L}$ of elastase from porcine pancrease $(0.03 \mathrm{Units} / \mathrm{mL})$ was added. The mixtures were further incubated for 
$10 \mathrm{~min}$ and the absorbance was measured at $410 \mathrm{~nm}$. Methanol was used as control, while oleanolic acid used as a positive control. The percentage of elastase inhibition was calculated as follows:

$$
\text { Elastase inhibition }(\%)=(1-\mathrm{B} / \mathrm{A}) \times 100
$$

where $\mathrm{A}$ is the enzyme activity without sample and $\mathrm{B}$ is the activity in the presence of the sample.

Acetylcholinesterase Inhibition Assay: Acetylcholinesterase (AChE) inhibitory activity was measured using Ellman's method as previously described [40] with minor modifications. AChE catalysis the hydrolysis of acetythiocholine iodide (ACTI as substrate) to thiocholine, which can then react with Ellman's reagent (DTNB) to produce 5-thio-2-nitrobenzoate (yellow color). In the presence of samples (inhibitors), the release of 5-thio-2-nitrobenzoate (yellow color) is reduced and it is monitored by measuring the absorbance at $450 \mathrm{~nm}$.

In a 96-Well plate, the reaction mixture contains $50 \mu \mathrm{L}$ of samples pre-incubated with $125 \mu \mathrm{L}$ of $3 \mathrm{mM}$ 5,5'-Dithiobis-(2-nitrobenzoic acid), and $25 \mu \mathrm{L} \mathrm{AChE}(2.0 \mathrm{U} / \mathrm{mL})$, in $50 \mathrm{mM}$ tris-HCl buffer (pH 8.0), with $0.1 \%$ bovine serum albumin (BSA) for 15 minutes at $25{ }^{\circ} \mathrm{C}$. Subsequently, $25 \mu \mathrm{L}(15 \mathrm{mM})$ ACTI was added to the incubation mixture and further incubated for $10 \mathrm{~min}$ at $25^{\circ} \mathrm{C}$. Sample control was prepared by adding sample solution to all reagents without $\mathrm{AChE}$, blank contained tris- $\mathrm{HCl}$ in the presence of AChE, while galanthamine was used as reference. Absorbance was recorded at $450 \mathrm{~nm}$. The percent AChE inhibitory activity is given by:

$$
\left[\mathrm{A}_{0}-(\mathrm{B}-\mathrm{C})\right] / \mathrm{A}_{0} \times 100
$$

where $\mathrm{A}_{0}=$ full enzymatic reaction; $\mathrm{B}=$ Activity in the presence of sample; and $\mathrm{C}=$ Activity without sample.

\section{Conclusions}

Fractionation of a methanol extract (HF) was carried out using standard chromatographic methods. A total of eleven pure compounds (1-11) were isolated, of which three were newly reported. Their chemical structures were established by spectroscopic methods. Several reports have convincingly shown a close relationship between antioxidant activity and the structural activity of phenolic compounds. On the basis of our findings, the prerequisite for a strong antioxidant activity assessed in these assays was the presence of an aromatic acyl-substituent, which may be valuable as a potential antioxidant and lipid peroxidation preventer, in the absence of prooxidant behavior. However, we had fully established the mode of actions through which the isolated compounds behave as a good source of antioxidant and moderate anti-tyrosinase and anti-elastase activities demonstrated by the Helichrysum niveum constituents. This study is the first report on in vitro antioxidant and aging-related enzyme inhibitory activity of a methanol extract of $H$. niveum and its constituents. The total antioxidant capacities and aging-related enzyme inhibitory activities demonstrated can be considered significant and informative as a guide for further studies.

\section{Acknowledgments}

The authors thank Stefan Abel, Institute of Biomedical and Microbial Biotechnology, Cape Peninsula University of Technology (South Africa), for the provision of S-9 Rat liver fraction and facilities for the 
isolation of microsomes, using gel filtration chromatography. Thanks to Benjamin Rodriguez, CSIC, Madrid, Spain for his assistance during the article preparation.

\section{Author Contributions}

O.K.P., J.L.M., and A.A.H. designed research; O.K.P., A.A.H., and E.I.I. performed chemistry part, analyzed the data, drafted the paper; and O.K.P., J.L.M., and F.R. performed the biological activity part, analyzed the data and drafted the paper. All authors read and approved the final manuscript.

\section{Conflicts of Interest}

The authors declare no conflict of interest.

\section{References}

1. Zhang, S.; Dong, Z.; Peng, Z.; Lu, F. Anti-aging effect of adipose-derived stem cells in a mouse model of skin aging induced by D-galactose. PLOS ONE 2014, 9, e97573.

2. Aiyegoro, A.O.; Okoh, I.A. Preliminary phytochemical screening and in vitro antioxidant activities of the aqueous extract of Helichrysum longifolium DC. BMC Complement Altern. Med. 2010, 10, 21-28.

3. Watson, R.E.B.; Gibbs, N.K.; Griffiths, C.E.M.; Sheraft, M.J. Damage to skin extracellular matrix induced by UV exposure. Antioxid. Redox Signal. 2014, 21, 1063-1077.

4. Carocho, M.; Ferreira, I. A review on antioxidants, prooxidants and related controversy: Natural and synthetic compounds, screening and analysis methodologies and future perspectives. Food Chem. Toxicol. 2013, 51, 15-25.

5. Vostalova, J.; Galandakova, A.; Pilakova, I.; Ulrichova, J.; Dolezal, D.; Lichnovska, R.; Vrbkova, J.; Rajnochova, A.; Svobodova, A.R. Lonicera caerulea fruits reduce UVA-induced damage in hairless mice. Photochem. Photobiol. B 2013, 128, doi:10.1016/j.jphotobiol.2013.07.024.

6. Factsheet-Helichrysum niveum-Lucid Key Server. Available online: htpp//www.keys.lucidcentral. org.13042015 (accessed on 17 September 2015).

7. Bohlmann, F.; Abraham, W.R. Polyacetylenic compounds. 250. New chloro-substituted acetylenic thiophenes with unusual structures from Helichrysum species. Phytochemistry 1979, 18, 839-842.

8. Dekker, T.G.; Fourie, T.G.; Snyckers, F.O.; Van der Schyf, C.J. Studies of South African medicinal plants. Part 2. Caespitin, a new phloroglucinol derivative with antimicrobial properties from Helichrysum caespititium. S. Afr. J. Chem. 1983, 36, 114-116.

9. Drewes, S.E.; van Vuuren, S.F. Antimicrobial acylphloroglucinols and dibenzyloxy flavonoids from flowers of Helichrysum gymnocomum. Phytochemistry 2008, 69, 1745-1749.

10. Haensel, R.; Cybulski, E.M.; Cubukcu, B.; Mericli, A.H.; Bohlmann, F.; Zdero, C. Naturally occurring terpene derivatives. Part 246. New pyrone derivatives from Helichrysum species. Phytochemistry 1980, 19, 639-644.

11. Jakupovic, J.; Zdero, C.; Grenz, M.; Tsichritzis, F.; Lehmann, L.; Hashemi-Nejad, S.M.; Bohlmann, F. Twenty-one acylphloroglucinol derivatives and further constituents from South African Helichrysum species. Phytochemistry 1989, 28, 1119-1131. 
12. Tomas-Lorente, F.; Iniesta-Sanmartin, E.; Tomas-Barberan, F.A.; Trowitzsch-Kienast, W.; Wray, V. Antifungal phloroglucinol derivatives and lipophilic flavonoids from Helichrysum decumbens. Phytochemistry 1989, 28, 1613-1615.

13. Bohlmann, F.; Abraham, W.F. Neue diterpene ud weitere inhaltsstoffe aus Helichrysum calliconum und Helichrysum heterolasium. Phytochemistry 1979, 18, 889-891.

14. Rios, J.L.; Recio, M.C.; Villar, A. Isolation and identification of the antibacterial compounds from Helichrysum stoechas. J. Ethnopharmacol. 1991, 33, 51-55.

15. Taglialatela-Scafati, O.; Pollastro, F.; Chianese, G.; Minassi, A.; Gibbons, S.; Arunotayanun, W.; Mabebie, B.; Ballero, M.; Appendino, G. Antimicrobial phenolics and unusual glycerides from Helichrysum italicum subsp. microphyllum. J. Nat. Prod. 2013, 76, 346-353.

16. Popoola, O.K.; Marnewick, J.L.; Rautenbach, F.; Ameer, F.; Iwuoha, E.I.; Hussein, A.A. Inhibition of oxidative stress and skin aging-related enzymes by prenylated Chalcones and other flavonoids from Helichrysum teretifolium. Molecules 2015, 20, 7143-7155.

17. Bohlmann, F.; Suwita, A. Neue phloroglucinol-derivative aus Leontonyx-arten sowie weitere Verbindungen aus verretern der Tribus Inuleae. Phytochemistry 1978, 17, 1929-1934.

18. Tabopda, T.K.; Ngoupayo, J.; Awoussong, P.K.; Mitaine-Offer, A.-C.; Ali, M.S.; Ngadjui, B.T.; Lacaille-Dubois, M.-A. Triprenylated flavonoids from Dorstenia psilurus and their $\alpha$-glucosidase inhibition properties. J. Nat. Prod. 2008, 71, 2068-2072.

19. Ren, X.-D.; Zhao, N.; Xu, S.; Lü, H.-N.; Ma, S.-G.; Liu, Y.-B.; Li, Y.; Qu, J.; Yu, S.-S. Total synthesis of illicidione A and illihendione A. Tetrahedron 2015, 71, 4821-4829.

20. Bohlmann, F.; Suwita, A. Further phloroglucinol derivatives from Helichrysum species. Phytochemistry 1979, 18, 2046-2049.

21. Bohlmann, F.; Mahanta, P.K. Further phloroglucinol derivatives from Helichrysum gymnoconum. Phytochemistry 1979, 18, 348-350.

22. Jakupovic, J.; Kuhnke, J.; Schuster, A.; Metwally, M.A.; Bohlmann, F. Phloroglucinol derivatives and other constituents from South African Helichrysum species. Phytochemistry 1986, 25, 1133-1142.

23. Barreirosa, M.L.; Davida, J.M.; de Pereiraa, R.A.; Guedesb, M.L.S.; David, J.P. Fatty acid esters of triterpenes from Erythroxylum passerinum. J. Braz. Chem. Soc. 2002, 13, 669-673.

24. Kang, S.-M.; Lee, S.-H.; Heo, S.-J.; Kim, K.-N.; Jeon, Y.-J. Evaluation of antioxidant properties of a new compound, pyrogallol-phloroglucinol-6,6'-bieckol isolated from brown algae, Ecklonia Cava. Nutr. Res. Pract. 2011, 5, 495-502.

25. Yang, H.; Protiva, P.; Gil, R.R.; Jiang, B.; Baggett, S.; Basile, J.M.; Reynertson, A.K.; Weinstein, B.; Kennelly, J.E. Antioxidant and cytotoxic isoprenylated coumarins from Mammea americana. Planta Med. 2005, 71, 852-860.

26. Jangu, J.M. Bioactive mammea-type coumarins and benzophenones from two clusiaceae plants. J. Pharm. Sci. Innov. 2012, 1, 31-33.

27. Queguineur, B.; Goya, L.; Ramos, S.; Martin, A.M.; Mateos, R.; Bravo, L. Phloroglucinol: Antioxidant properties and effects on cellular oxidative markers in human HepG2 cell line. Food Chem. Toxicol. 2012, 50, 2886-2893.

28. Sun, Q.; Schmidt, S.; Tremmel, M.; Heilmann, J.; Konig, B. Synthesis of natural-like acylphloroglucinols with anti-proliferative, anti-oxidative and tube-formation inhibitory activity. Eur. J. Med. Chem. 2014, 85, 621-628. 
29. Roleira, M.F.F.; Siquet, C.; Orru, E.; Garrido, M.; Garrido, J.; Milhazes, N.; Podda, G.; Paiva-Martins, F.; Reis, S.; Carvalho, A.R.; et al. Lipophilic phenolic antioxidants: correlation between antioxidant, partition coefficients and redox properties. Bioorg. Med. Chem. 2010, 18, $5816-5825$.

30. Lee, D.-S.; Cho, Y.-S.; Je, J.-Y. Antioxidant and antibacterial activities of chitosan-phloroglucinol conjugate. J. Fish Aquat. Sci. 2013, 16, 229-235.

31. Lee, S.-M.; Na, M.-K.; An, R.-B.; Min, B.-S.; Lee, H.-K. Antioxidant activity of two phloroglucinol derivatives from Dryopteris crassirhizoma. Biol. Pharm. Bull. 2003, 26, 1354-1356.

32. Prasad, K.N.; Yang, B.; Yang, S.; Chen, Y.; Zhao, M.; Ashraf, M.; Jiang, Y. Identification of phenolic compounds and appraisal of antioxidant and antityrosinase activities from litchi (Litchi sinensis sonn.) seeds. Food Chem. 2009, 116, 1-7.

33. Chang, T.-S. An update review of tyrosinase inhibitors. Int. J. Mol. Sci. 2009, 10, 2440-2475.

34. Feisst, C.; Franke, L.; Appendino, G.; Werz, O. Identification of molecular targets of the oligomeric nonprenylated acylphloroglucinols from Myrtus communis and their implication as anti-inflammatory compounds. J. Pharmacol. Exp. Ther. 2005, 315, 389-396.

35. Colovic, B.M.; Krstic, D.Z.; Lazaveric-Pastic, D.T.; Bondzic, M.A.; Vasic, M.V. Acetylcholinesterase inhibitors: Pharmacology and toxicology. Curr. Neuropharmacol. 2013, 11, 315-335.

36. Wagner, H.; Bladt, S. Flavonoid drug including Ginkgo biloba and Echinaceae species. In Plant Drug Analysis: A thin Layer Chromatography Atlas, 2nd ed.; Springer-Verlag: Berlin, Germany, 1996; pp. 196, 197, 364.

37. Benzie, I.; Strain, J. The ferric reducing ability of plasma (FRAP) as a measure of "antioxidant power": The FRAP Assay. Anal. Biochem. 1996, 238, 70-76.

38. Pellegrini, N.; Re, R.; Yang, M.; Rice-Evans, C.A. Screening of dietary carotenoid-rich fruit extracts for antioxidant activities applying ABTS radical cation decolorisation assay. Methods Enzymol. 1999, 299, 379-389.

39. Snijman, P.W.; Joubert, E.; Ferreira, D.; Li, X.; Ding, Y.; Green, I.R.; Gelderblom, W.C.A. Antioxidant activity of the dihydrochalcones aspalathin and nothofagin and their corresponding flavones in relation to other rooibos (Aspalathus linearis) flavonoids, epigallocatechin gallate, and trolox. J. Agric. Chem. 2009, 57, 6678-6684.

40. Zengin, G.; Sarikurkcu, C.; Aktumsek, A.; Ceylan, R.; Ceylan, O. A comprehensive study on phytochemical characterization of Haplophyllum myrifolium Bioss. endemic to Turkey and its inhibitory potential against key enzymes involved in Alzheimer, skin diseases and type II diabetes. Ind. Crops Prod. 2014, 53, 244-254.

Sample Availability: Samples of the compounds 4-9 are available from the authors.

(C) 2015 by the authors; licensee MDPI, Basel, Switzerland. This article is an open access article distributed under the terms and conditions of the Creative Commons Attribution license (http://creativecommons.org/licenses/by/4.0/). 